\title{
THE EFFECT OF ARTIFICIAL PNEUMOTHORAX UPON THE ANOXEMIA OF PNEUMONIA ${ }^{1}$
}

\author{
By DAVID GOLDSTEIN, MORRIS BLOCK, AND MILTON ROSENBLÜTH \\ (From the Departments of Medicine and Physiology of the New York University College of \\ Medicine and the Third (New York University) Medical Division of Bellevue \\ Hospital, New York City)
}

(Received for publication May 26, 1938)

Statements concerning the usefulness of pneumothorax in alleviating the anoxemia of lobar pneumonia are few and conflicting, and are limited to estimates based upon the degree of cyanosis, the severity of dysprea, and other criteria which are only roughly quantitative. It seemed that an examination of the effect of pneumothorax upon the degree of oxygen saturation of the arterial blood would afford more reliable information on the therapeutic value of this measure.

The following is a report on the oxygenation of blood in six cases of unilateral preumococcus lobar pneumonia treated with pneumothorax. Diagnosis was based upon the usual clinical criteria and verified by $x$-ray. Only cases in whom pneumothorax could be instituted within 72 hours of the onset of the disease were selected for study. These were chosen irrespective of the type of pneumococcus. Pneumococcus serum was given in only one instance. In establishing pneumothorax the technique of Blake (1) was employed, except that air was introduced at a rate of about $40 \mathrm{cc}$. per minute, and collapse of the lung was carried out as completely and rapidly as was consistent with the comfort and safety of the patient. In certain cases mediastinal shift, adhesions, and massive consolidation limited the extent of collapse. Pneumothorax was performed in the lateral recumbent position, and inspiratory, expiratory, and mean intrapleural pressures were recorded before and after the introduction of air.

Arterial oxygen saturation was determined before the institution of pneumothorax, about two hours after separation of the pleura, during several stages of collapse, and then throughout the disease and at less frequent intervals during convalescence. Serial roentgenograms were taken during the observation of each case by means of a 10 milliampere portable bedside unit. Arterial

1 This study was supported in part by a gift from $\mathrm{Mr}$. Bernard Baruch. blood was collected by puncture of the radial artery without novocaine.

\section{METHOD}

Ten cc. of blood were drawn into an oiled syringe containing sufficient powdered oxalate to make a 0.2 per cent solution. The blood was transferred without exposure to air and without negative pressure to a storage flask filled with mercury by means of a close-fitting rubber junction. Samples for analysis were transferred in a similar manner to a Van Slyke-Ostwald pipette. Equilibration with air was carried out in a mechanically rotated tonometer at room temperature. All analyses were made in duplicate by means of a Van Slyke manometric apparatus and according to the method of Van Slyke and Neill (2). The average deviation observed in duplicate oxygen determination was \pm 0.25 per cent; the precision of the saturation figures may therefore be taken as \pm 0.5 per cent. We obtained 93.0 per cent (range 90 to 96 per cent) as the mean value for the arterial saturation in six normal subjects, a figure in close agreement with the data recently published by Looney and Jellinek (3). Careful examination of the technique leads us to agree with these authors that the often quoted figure of 95 per cent for the saturation of normal arterial blood is erroneously high because of the practice of allowing the blood to stand in contact with oil. We find that the oxygen content of blood remains constant for a period of five hours when it is chilled immediately after collection and preserved over mercury, whereas there is continuous diffusion of oxygen into the blood when it is preserved under oil at the same temperature, particularly when samples are being removed and the blood must be agitated. All blood gas analyses reported here were made within five hours of the time the blood was drawn.

\section{RESULTS}

A summary of the significant data in the six cases studied is presented in Table I. Separation of the pleura was associated with a small rise in arterial saturation in two patients (T. C. and W. T.), with no change in two (W. D. and F. J.) and with a slight fall in two (J. J. and B. T.). 
TABLE I

Summary of data

\begin{tabular}{|c|c|c|c|c|c|c|c|c|c|c|c|c|c|}
\hline \multirow{2}{*}{ Name } & \multirow{2}{*}{ Age } & \multirow[b]{2}{*}{ Sex } & \multirow[b]{2}{*}{ Type } & \multirow{2}{*}{$\begin{array}{l}\text { Blood } \\
\text { culture }\end{array}$} & \multirow{2}{*}{$\begin{array}{c}\text { Duration } \\
\text { of } \\
\text { disease } \\
\text { before } \\
\text { pneumo- } \\
\text { thorax }\end{array}$} & \multirow{2}{*}{$\begin{array}{c}\text { Involve- } \\
\text { ment* }\end{array}$} & \multicolumn{3}{|c|}{ Oxygen saturation } & \multirow{2}{*}{$\begin{array}{l}\text { Degree of } \\
\text { collapse }\end{array}$} & \multirow{2}{*}{$\begin{array}{l}\text { Effect on } \\
\text { respira- } \\
\text { tory } \\
\text { rate }\end{array}$} & \multirow{2}{*}{$\begin{array}{l}\text { Effect on } \\
\text { pain }\end{array}$} & \multirow{2}{*}{$\begin{array}{l}\text { Effect on } \\
\text { temperature }\end{array}$} \\
\hline & & & & & & & $\begin{array}{c}\text { Before } \\
\text { pneumo- } \\
\text { thorax }\end{array}$ & $\begin{array}{l}\text { Sepa- } \\
\text { ration } \\
\text { of } \\
\text { pleura }\end{array}$ & $\begin{array}{l}\text { After } \\
\text { collapse }\end{array}$ & & & & \\
\hline J. J......... & $\begin{array}{c}\text { years } \\
48\end{array}$ & $\mathbf{M}$ & XIV & $\begin{array}{c}\text { Nega- } \\
\text { tive }\end{array}$ & 40 hours & $\underset{\text { RUL }}{\text { RLL }} \rightarrow$ & $\begin{array}{c}\text { per cent } \\
91.0\end{array}$ & $\begin{array}{c}\text { per cent } \\
87.2\end{array}$ & $\begin{array}{c}\text { per cent } \\
85\end{array}$ & Complete & None & $\begin{array}{l}\text { Mild } \\
\text { pleural } \\
\text { pain re- } \\
\text { lieved by } \\
\text { pneumo- } \\
\text { thorax }\end{array}$ & None \\
\hline B. T......... & 35 & $\mathbf{M}$ & Uncl. & $\begin{array}{c}\text { Nega- } \\
\text { tive }\end{array}$ & 54 hours & LLL & 89.0 & 86.0 & 86 & $\begin{array}{l}20 \text { per cent } \\
\text { with apical } \\
\text { adherence }\end{array}$ & None & $\begin{array}{l}\text { Mild } \\
\text { pleural } \\
\text { pain } \\
\text { with } \\
\text { relief }\end{array}$ & None \\
\hline F.J.......... & 46 & $\mathbf{F}$ & I & $\begin{array}{c}\text { Nega- } \\
\text { tive }\end{array}$ & 3 days & RLL & 82.0 & 82.0 & 69 & 40 per cent & None & None & Questionable \\
\hline T.C......... & 40 & $\mathbf{M}$ & II & $\begin{array}{c}\text { Nega- } \\
\text { tive }\end{array}$ & $\begin{array}{l}\text { Less } \\
\text { than } \\
3 \text { days }\end{array}$ & RLL & 83.0 & 88.0 & 83 & $\begin{array}{l}20 \text { per cent. } \\
\text { consol. } \\
80 \text { per cent } \\
\text { normal }\end{array}$ & None & $\begin{array}{l}\text { Severe } \\
\text { pain- } \\
\text { relieved }\end{array}$ & $\begin{array}{l}\text { Questionable } \\
\text { depression }\end{array}$ \\
\hline w. D........ & 29 & $\mathbf{M}$ & Uncl. & $\begin{array}{c}\text { Nega- } \\
\text { tive }\end{array}$ & 14 hours & RLL & 88.5 & $\begin{array}{l}88.7 \\
89.7\end{array}$ & 87 & 90 per cent & $\begin{array}{l}\text { Fell: } \\
40 \text { to } 30 \\
\text { to } 22\end{array}$ & $\begin{array}{l}\text { Slight } \\
\text { relief }\end{array}$ & $\begin{array}{l}\text { Suggesto } \\
\text { fall }\end{array}$ \\
\hline W.T........ & 46 & $\mathbf{M}$ & I & $\begin{array}{c}\text { Nega- } \\
\text { tive }\end{array}$ & 3 days & $\begin{array}{c}\text { RUL } \rightarrow \\
\text { LULL } \\
\text { LLL }\end{array}$ & 85.2 & 88.2 & 77 & $\begin{array}{l}50 \text { per cent } \\
\text { adherent }\end{array}$ & $\begin{array}{l}\text { De- } \\
\text { pressed } \\
\text { rate for } \\
\text { one day }\end{array}$ & $\begin{array}{l}\text { Notable } \\
\text { on sepa- } \\
\text { ration of } \\
\text { pleura, } \\
\text { but } \\
\text { tempo- } \\
\text { rary }\end{array}$ & None \\
\hline
\end{tabular}

* RLL-Right lower lobe. RUL-Right upper lobe. LLL-Left lower lobe. LUL-Left upper lobe.

Further collapse of the lung was accompanied by no significant change in arterial saturation in two patients, and by reduction in saturation in four. In two of the latter the oxygen content of the arterial blood was reduced to critically low levels-69 per cent and 77 per cent.

Our discussion of the rationale of the use of pneumothorax in lobar pneumonia will be confined to its influence upon anoxemia. The anoxemia of pneumonia patients is of the anoxic type. There are varied opinions concerning the mechanism by which this anoxemia is produced. That shallow breathing is not a major factor has been demonstrated by Binger and Davis (4). Altered vital capacity, acceleration of blood flow through normal lung tissue, and altered alveolar permeability have been suggested as causal factors by Binger and Brow (5), Binger, Brow, and Branch (6), and others. It appears that the most pertinent and at the same time most debated question concerns the extent to which the circulation in the consolidated involved lung tissue is impaired.
Since human autopsy and experimental material indicate that capillary patency is rarely completely lost, it is frequently argued that the benefit of oxygen therapy in pneumonia is due to increasing the availability of oxygen in alveoli which are relatively unaerated because of the mechanical barrier of alveolar and bronchial exudates $(7,8)$. In this view the major factor leading to anoxemia is the presence of inadequately aerated channels in the consolidated lobe. If this is the case, the induction of pneumothorax in lobar pneumonia can alleviate anoxemia only if blood is deflected from the collapsed to the intact lobes, as apparently happens in the normal or tuberculous individual. But it appears unwarranted to argue the value of pneumothorax in lobar preumonia by analogy with the normal or tuberculous subject in whom pneumothorax rarely lowers arterial saturation, and where, if saturation is lowered by unilateral lesions, pneumothorax may increase it (9). It is possible that because of consolidation of the lung, pneumothorax in lobar pneumonia does not effectively close the capillary circulation 
in unaerated tissue despite convincing evidence of adequate collapse by $\mathbf{x}$-ray. It is also possible that collapse of an uninvolved lobe may actually increase the blood flow through consolidated tissue on the same side. But even if deflection to normal tissue occurs, the rate of blood flow may be too great to permit gaseous equilibration when it is recognized that the rate of metabolism and cardiac output in the febrile pneumonia patient is considerably increased. It is thus evident that the cause of anoxemia in lobar pneumonia cannot be ascertained with any certainty until information concerning the circulation in consolidated and unconsolidated lung tissue is available.

In two of our patients the oxygen saturation rose after separation of the pleura, but these patients were suffering severe pleural pain prior to induction of pneumothorax, and there was marked relief from this pain following the treatment. We believe that the rise in saturation in these patients was caused by increased ventilation associated with relief from pain. The fact that oxygen saturation after maximal collapse was unchanged in two of our patients and decreased in four others argues against the supposition, as stated above, that pneumothorax deflects blood from unaerated to aerated capillary beds; certainly if this occurs, then the latter are inadequate to afford full oxygenation to the increased circulation. But regardless of the physiological interpretation, in the six cases studied, pneumothorax was without value for the relief of anoxemia.

The carbon dioxide content of each blood sample collected was determined. Since the figures fall roughly within the normal range of 45 to 55 volumes per cent, in agreement with previous investigations in lobar pneumonia, they are not reported.

\section{CONCLUSIONS}

1. Six cases of early pneumococcus pneumonia of various types were given pneumothorax. Five cases showed diminished oxygen saturation of the arterial blood at the outset (range, 82 to 89

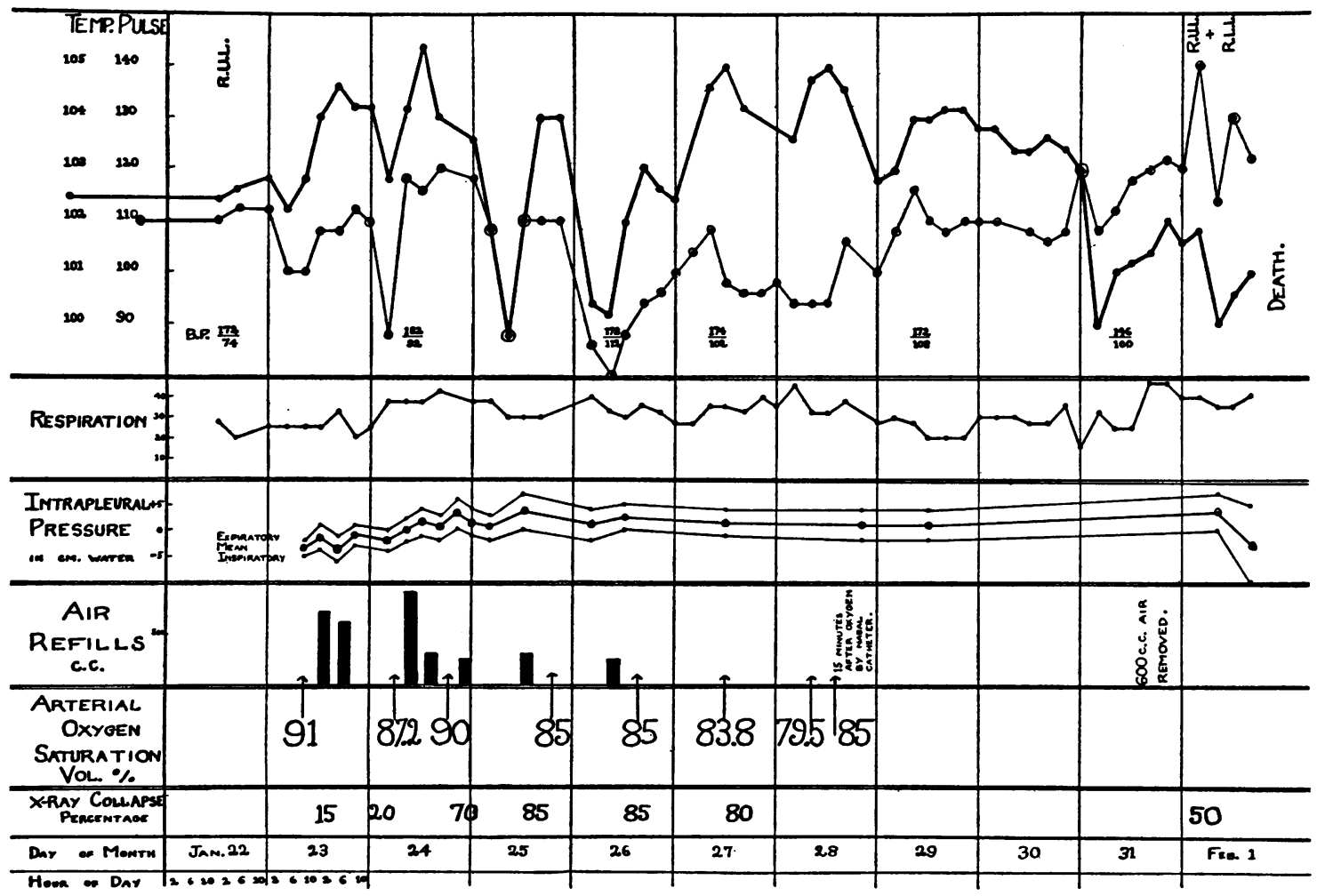

Fig. 1. J. J., Number 26243, Male 48. R.L.L. Pneumonia. Pneumococcus Type Xiv. Blood Culture Negative Throughout. Initial Pneumothorax 40 Hours After Onset 
per cent). The extent of final collapse estimated by $x$-ray varied from 30 to 90 per cent.

2. Separation of the pleura (initial pneumothorax) was followed by (a) no change in oxygen saturation in two cases, $(b)$ a fall in oxygen saturation in two cases, $(c)$ a rise in oxygen saturation in two cases. This group exhibited the most severe pleural pain, and the greatest relief after pneumothorax.

3. Further collapse of the lung in no case was attended by an increase in oxygen saturation above the initial level. In four cases, the oxygen saturation fell, after establishing collapse of the involved lung.

\section{PROTOCOLS}

Case J. J., Number 26243 (Figure 1). A 48-year old negro porter was admitted January 22, 1937, two days after onset with chilliness and generalized aches and pains. There was no history of previous pulmonary disease. On physical examination, there was dullness over the right lower lobe, bronchial breathing, and showers of crepitant râles. Sputum examination showed Type
XIV pneumococcus. In addition to the diagnosis of pneumococcus pneumonia, right lower lobe, the additional diagnoses of hypertensive and luetic heart disease with enlarged heart and dilated aorta were made.

Laboratory. Blood cultures taken January 23 and 27 were sterile. Leukocytes ranged between 20,000 and 30,000 , granulocytes 90 to 94 per cent. Electrocardiogram showed left deviation of the electrical axis, and regular sinus rhythm.

There was a fall in the arterial oxygen saturation in the presence of good collapse: in the latter stages this may have been attributable to the development of a spread to the upper lobe. During the first days of fall, there was neither $\mathbf{x}$-ray nor clinical evidence of new involvement. There was mild relief of pleural pain, with no associated rise in saturation on pleural separation. Pneumothorax did not prevent a fall in saturation in this patient.

The patient died on February 1, 1937, the 13th day after onset.

At postmortem right lower lobe and more recent right upper lobe consolidations were found. Additional findings were fibrinous pleuritis with effusion on the right, hypertensive and arteriosclerotic heart disease. The blood culture was negative.

Case B. T., Number 26023 (Figure 2). A 35-year

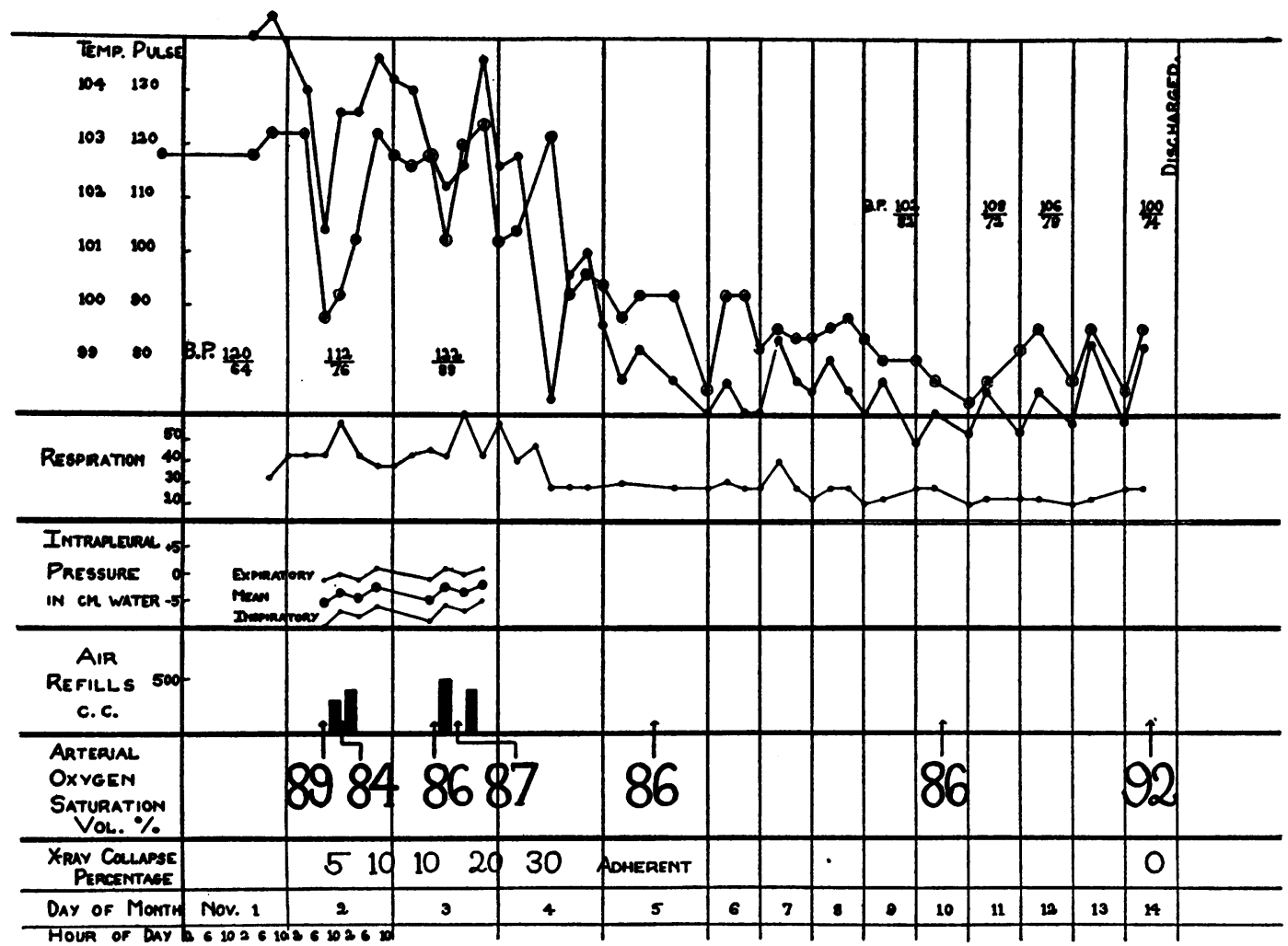

Fig. 2. B. T., Number 26023, Male 35. L.L.L. Pneumonia. Unclassified Pneumococcus. Blood Culture Negattve. Initial Pneumothorax 54 Hours After Onset 
old handyman had the onset of his disease with chill, thoracic pain, fever, cough, and scanty yellow expectoration at 7:30 a.m. on October 31, 1936. There was no history of previous pulmonary disease. Physical signs in the lung were dullness over the lower half of the posterior left chest, and showers of inspiratory râles.

Laboratory. Blood culture taken November 1, 1936 was sterile, leukocytes 13,950 , granulocytes 83 per cent. Sputum unclassified Pneumococcus Types I through XIV.

Diagnosis. Pneumococcus pneumonia of left lower lobe.

A very partial collapse was obtained. Crisis occurred on the fifth day. Arterial oxygen saturation seemed relatively unaffected by pneumothorax. There was a persistence of unsaturation throughout the six days following crisis, despite good re-expansion. During this period, chest signs were minimal.

Case F. J., Number 26281 (Figure 3). A white Polish housewife, 46 years of age, was admitted on January 6 , 1937. Two weeks preceding admission she had had a head cold and cough. On January 5, she expectorated a cupful of bloody sputum. She had generalized chest pain and-several chills. It was estimated that at the time of admission the pneumonia was of three days' duration. In the past history, the patient was a known diabetic, taking insulin 15-0-0 without a well-regulated diet. On physical examination there was dullness over the right lower lobe, without alteration in breath or voice sounds. The abdomen was not distended.

Laboratory. Sputum was thick and tenacious and Type I pneumococcus was found in the sputum. Leukocyte count was 15,850 , with 74 per cent granular cells of which 23 per cent were stab forms, hemoglobin 12.6 grams ( 87 per cent), R.B.C. 3.47 million. The diagnosis of Type I pneumococcus pneumonia, right lower lobe, was made. Blood culture was negative throughout. The diabetes was controlled on a diet of, carbohydrate 150 , protein 65 , fat 85 : insulin $20-10-20$, the latter being reduced to 5-0-0 before discharge. No serum was given.

There was progressive fall in arterial oxygen saturation within increasing collapse despite the absence of clinical evidence of mediastinal shift or pneumonia spread. On the third day of collapse, acute respiratory distress supervened. At this time, the oxygen saturation was 69 per cent and the mean intrapleural pressure was +2 , respirations were 30 per minute, and cyanosis was intense. On removal of $600 \mathrm{cc}$. of air, mean intrapleural pressure was minus one $\mathrm{cm}$. of water. Twelve hours later, saturation in an oxygen tent was 80 per cent: when the patient was removed from the tent, the saturation fell to 62 per cent. This episode was associated with a fall in temperature, which shortly after returned to normal.

Case T. C., Number 26124 (Figure 4). A 40-year

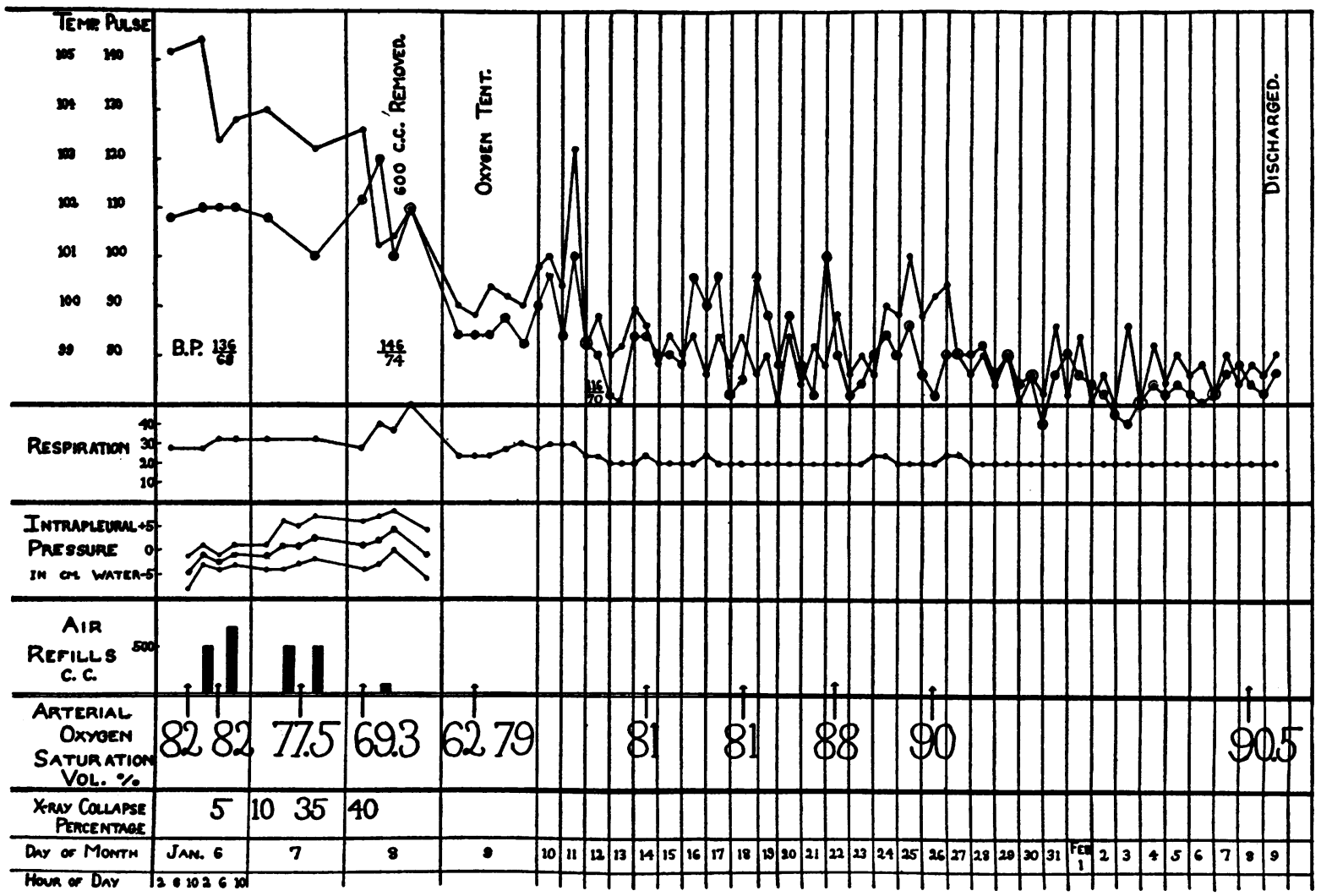

Fig. 3. F. J., Number 26281, Female 46. R.L.L. Pneumonia. Pneumococcus Type I. Blood Culture Negative Throughout. Initial Pneumothorax 72 Hours After Onset 


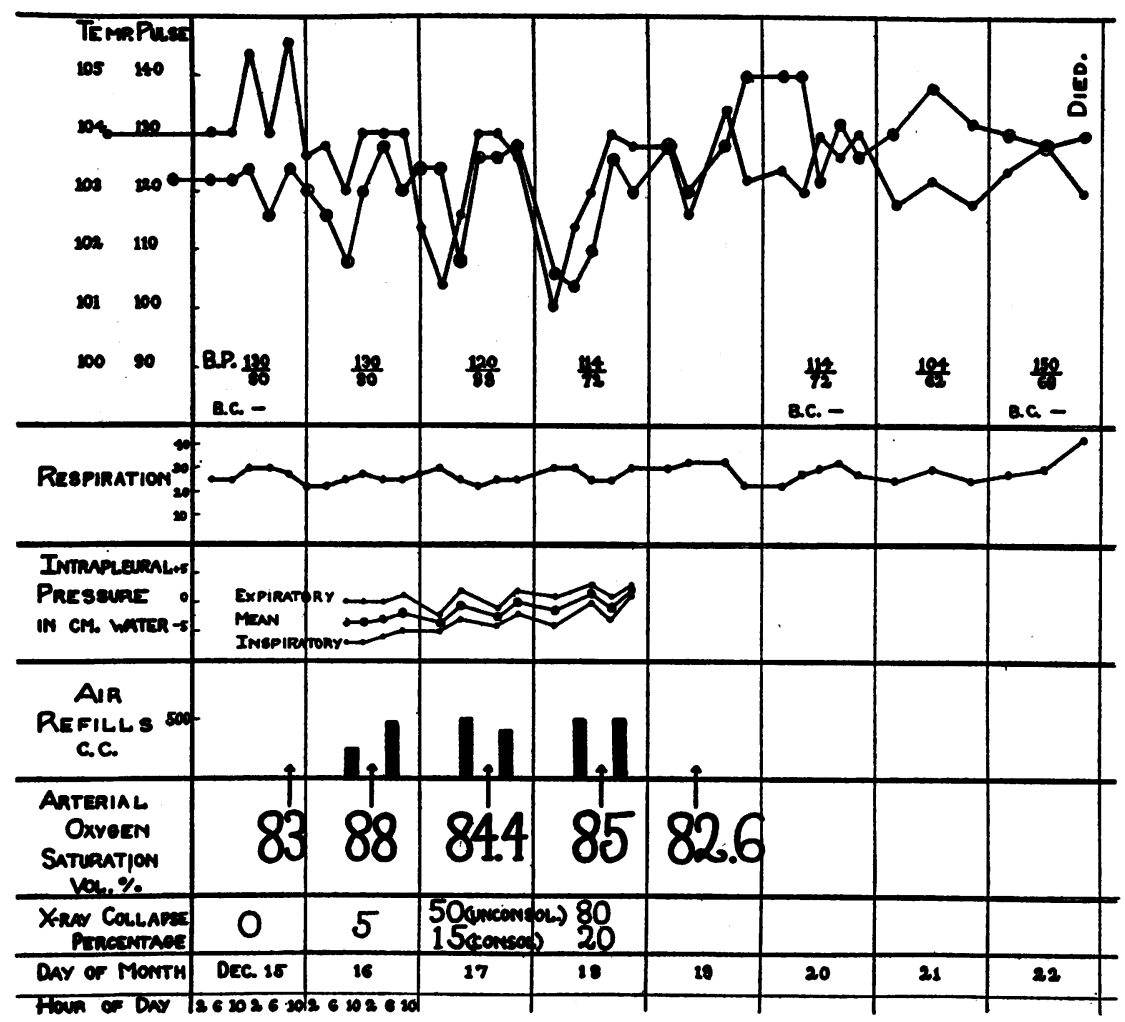

Fig. 4. T. C., Number 26124, Male 40. R.L.L. Pneumonia. Pneumococcus

Type II. Blood Culture Negative Throughout. Initial Pneumothorax Less

Than 72 Hours After Onset. Treated with 200,000 Units Type II Serum.

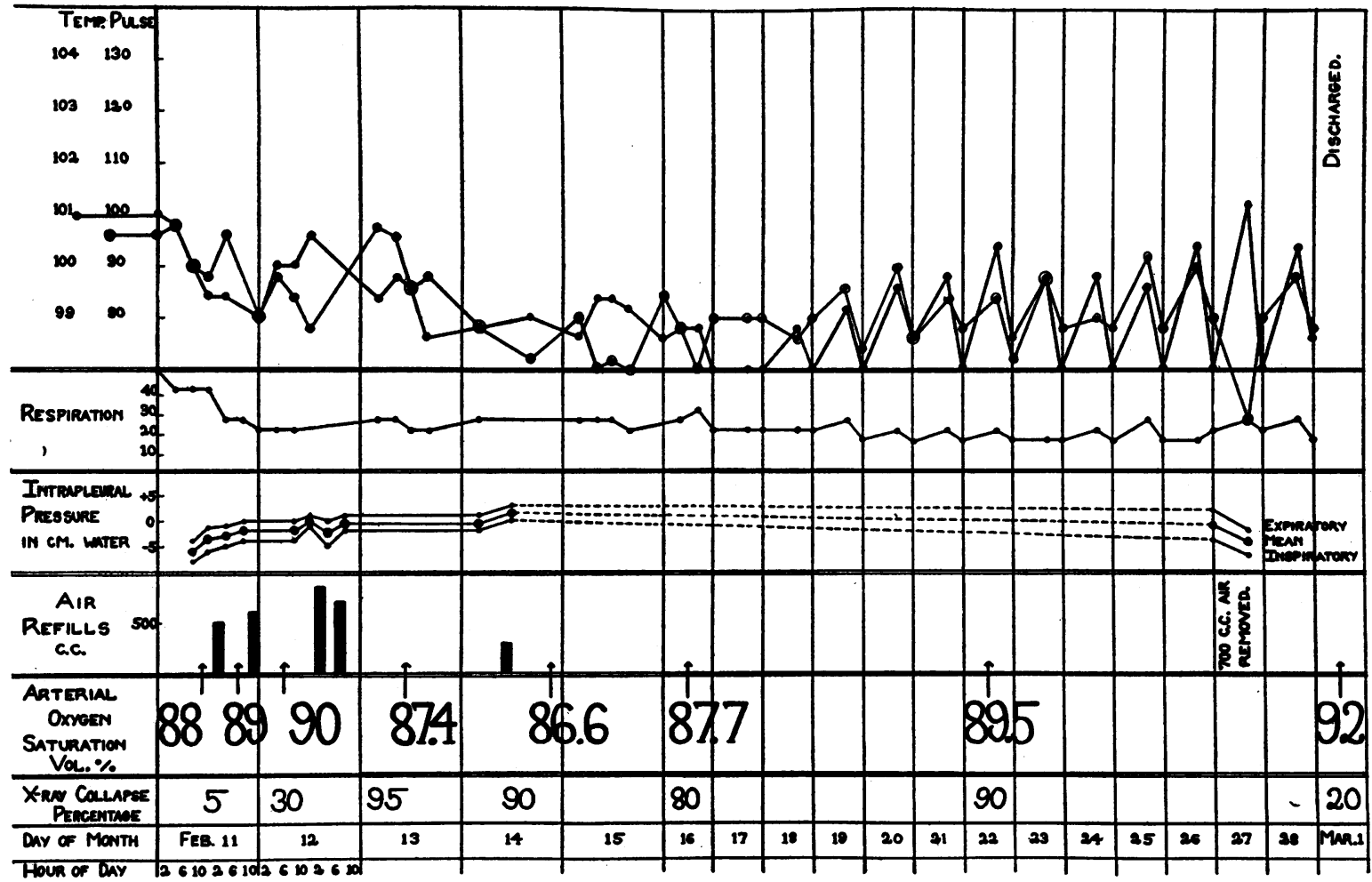

Fig. 5. W. D., Number 26442, Male 29. R.L.L. Pneumonia. Unclassified Pneumococcus. Blood Culture Negattve Throughout. Initial Pneumothorax 14 Hours After Onset 
old truck driver complained of malaise and mild pain over lower right axilla beginning December 13, 1936 and lasting to the time of admission December 15, 1936. Chills, cough, and marked pleural pain appeared on December 14, 1936. A convulsion on the morning of December 15, 1936 prompted hospitalization.

Past history was negative for previous pulmonary disease. Patient had experienced convulsive seizures for the past five years. Physical examination of the lungs revealed no abnormal findings. Fluoroscopy and $x$-ray revealed a definite shadow over the right lower lobe.

Laboratory. Sputum tenacious and rusty, in which a Type II pneumococcus was found. Blood cultures December 15,20 , and 22 were sterile. Leukocytes ranged between 26,000 and 50,000, granulocytes 90 to 91 per cent.

Course. 200,000 units Type II antipneumococcus serum were given.

Diagnosis. Pneumococcus pneumonia. Patient died on the 9th day of his illness.

Associated with the relief of pleural pain following separation of the pleura, the oxygen saturation rose from 83 to 88 per cent. With subsequent refills, however, the saturation fell. There was 20 per cent collapse of the right lower lobe, and 80 per cent collapse of the uninvolved lobes. Pneumothorax was discontinued because it was felt that consolidation interfered with further collapse. The final mean intrapleural pressure reading was $+2 \mathrm{~cm}$. of water. The patient died. Permission for autopsy was not obtained.

Case W. D., Number 26442 (Figure 5). A 29-year old waiter awoke with a chill at 1 a.m. on February 11, 1937 followed by posterior right chest pain several hours later. Slight cough was present, with no expectoration. Past history revealed nothing but "grippe" in 1935. Physical examination of the chest showed marked dullness over right base posteriorly, absent breath sounds, and no râles. X-ray showed a small shadow in the right lower lung field adjacent to the hilum.

Laboratory. Unclassified pneumococcus, Types I to VIII and XIV were found in the sputum, leukocytes 13,000 to $27,000,82$ to 88 per cent granular cells. Blood culture taken February 11th was sterile.

Diagnosis. Pneumococcus pneumonia of right lower lobe.

Despite complete collapse (90 per cent) unassociated with mediastinal shift, unsaturation continued for twelve days following fall in temperature.

Case W. T., Number 26348 (Figure 6). A 46-year old steel worker complained of chill, chest pain, cough, fever, and diarrhea of three days' duration. There was no expectoration. Headache and chest pain were very severe on admission. Past history was negative except for a chancre in 1905 inadequately treated.

Physical findings revealed dullness, diminished breath

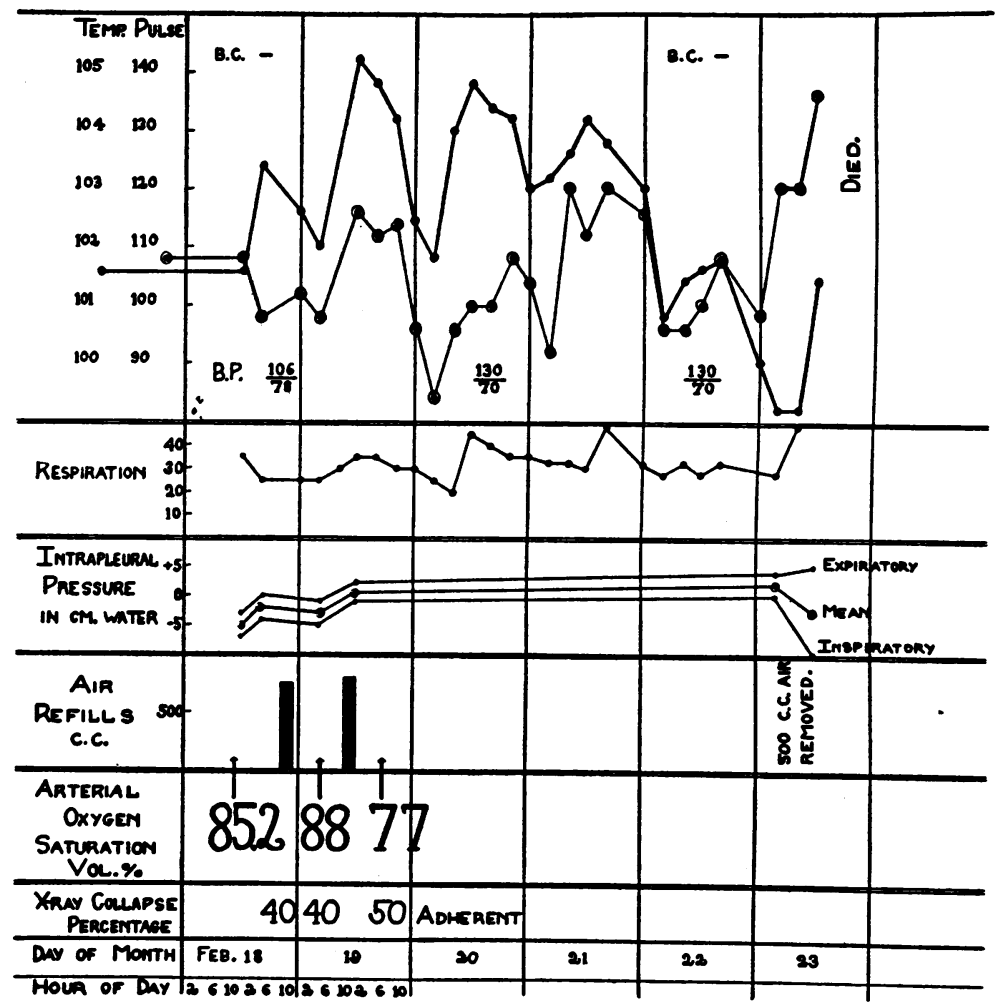

Fig. 6. W. T., Number 26348, Male 46. R.U.L. Pneumonia. PneUmococcus Type I. Blood Culture Negative Throughout. Initial Pneumothorax Less Than 72 Hours After Onset. 
sounds, and a friction rub high in the right axilla. Heart: Position of maximal impulse was not felt. Sounds were of good quality. $A_{2}$ was greater than $P_{2}$. There were no murmurs and the rhythm was regular. $\mathrm{X}$-ray showed a dilated aorta.

Laboratory. Blood cultures taken February 20 and 22 were sterile. Leukocytes ranged from 19,950 to 39,000 ; granulocytes 93 to 95 per cent. Wassermann \pm , sputum Type I pneumococcus.

Diagnosis. Pneumococcus pneumonia Type I of right upper lobe, luetic aortitis.

Only 50 per cent collapse was obtained because of an apical adhesion (confirmed at postmortem examination). A transient slight rise in arterial oxygen saturation was obtained on separation of pleura, seemingly associated with definite relief of pleural pain. Following the first refill on the second hospital day, saturation fell from 88 per cent to 77 per cent. There was no $x$-ray evidence of spread at this time, and no shift of the mediastinum. Death occurred on the sixth hospital day. At postmortem examination there was an empyema on the right side, with spread of the pneumonia to the left upper lobe and left lower lobe. Syphilitic aortitis and aortic insufficiency also were found.

\section{BIBLIOGRAPHY}

1. Blake, Francis G., Howard, Marion E., and Hull, Winifred S., Artificial pneumothorax in lobar pneumonia. Medicine, 1936, 15, 1.
2. Van Slyke, D. D., and Neill, J. M., The determination of gases in blood and other solutions by vacuum extraction and manometric measurement. I. J. Biol. Chem., 1924, 61, 523.

3. Looney, J. M., and Jellinek, E. M., The oxygen and carbon dioxide content of the arterial and venous blood of normal subjects. Am. J. Physiol., 1937, 118, 225.

4. Binger, C. A. L., and Davis, J. S., Jr., The relation of anoxemia to the type of breathing in pneumonia. A study of respiration by means of a body plethysmograph. J. Clin. Invest., 1928, 6, 171.

5. Binger, C. A. L., and Brow, G. R., Studies on the respiratory mechanism in lobar pneumonia; a study of lung volume in relation to the clinical course of the disease. J. Exper. Med., 1924, 39, 677.

6. Binger, C. A. L., Brow, G. R., and Branch, A., Experimental studies on rapid breathing. II. Tachypnea, dependent upon anoxemia, resulting from multiple emboli in the larger branches of the pulmonary artery. J. Clin. Invest., 1924, 1, 155.

7. Peters, J. P., and Van Slyke, D. D., Quantitative Clinical Chemistry. Vol. I. Interpretations. Williams and Wilkins Co., Baltimore, 1932, p. 601.

8. Binger, C. A. L., Anoxemia in pneumonia and its relief by oxygen inhalation. J. Clin. Invest., 1928, $6,203$.

9. Meakins, J. C., and Davies, H. W., Respiratory Function in Disease. Oliver, Edinburgh, 1925. 